\title{
MinOANS In NeW YorK
}

\section{BY ROBERT B. KOEHL}

From the Land of the Labyrinth: MinOan CRete, 3000-1100 B.C., Onassis Cultural Center, New York, 13 March-13 September, 2008, curated by Maria Andreadaki-Vlazaki, Vili Apostolakou, and Nota DimopoulouRethemiotaki.

From the Land of the Labyrinth: Minoan Crete, 3000-1100 B.C., edited by Maria AndreadakiVlazaki, Giorgos Rethemiotakis, and Nota Dimopoulou-Rethemiotaki. Pp. 295, b\&w figs. 29, color figs. 257, maps 2. Alexander S. Onassis Public Benefit Foundation (USA) and Hellenic Ministry of Culture, Archaeological Museums of Crete, Greece, 2008. \$20. ISBN 978-0-9776598-2-1 (paper).

Since opening its doors in New York City in October 2000, the Onassis Cultural Center has been host to a stream of splendid exhibitions largely devoted to introducing the North American public to the rich cultural heritage of Greece, both ancient and modern. The current exhibition, From the Land of the Labyrinth: Minoan Crete, 3000-1100 B.C., is the first one in the United States devoted exclusively to the Bronze Age civilization of Crete, coined "Minoan" by Sir Arthur Evans, doyen of Cretan Bronze Age archaeology. Although collections of Minoan artifacts exist in the United States, most of these comprise specimens that lack a provenance and include some notorious pieces of dubious authenticity. ${ }^{1}$ There are exceptions, such as the collection in the University of Pennsylvania Museum of Archaeology and Anthropology in Philadelphia, which comes from museum-sponsored excavations in east Crete during the early 20th century. ${ }^{2}$ The re-

\footnotetext{
${ }^{1}$ Lapatin 2002.

${ }^{2}$ Betancourt 1983; Betancourt and Silverman 1991.
}

cently opened study collection of Greek and Roman art at the Metropolitan Museum of Art includes representative Minoan artifacts with provenances, which supplement the museum's regular display of artifacts with and without provenances. ${ }^{3}$ A small exhibition of Minoan and Mycenaean objects from various American and European collections was mounted in 1967 at Smith College in Northampton, Massachusetts, in memory of Harriet Boyd Hawes, a pioneer of Minoan archaeology. ${ }^{4}$ A Minoan exhibition in Karlsruhe, Germany, in 2001 was mired in controversy for displaying undocumented Minoan artifacts from a private collection alongside material from archaeological museums on Crete and other European public institutions.

None of these moral dilemmas or questions of authenticity need trouble the visitor to the exhibition reviewed here. Culled exclusively from the archaeological museums of Crete-in Haghios Nikolaos, Herakleion, Hierapetra, Khania, Rethymnon, and Siteia-most of the 281 artifacts on display derive from controlled excavations, and several others were chance finds made on the island. Some of the objects are relatively recent discoveries displayed publicly for the first time.

The Onassis Cultural Center, located in the basement of the Olympic Tower on Fifth Avenue, is the gallery of the Alexander S. Onassis Public Benefit Foundation (USA). This gallery seems particularly well-suited to artifacts from Crete (fig. 1). Its large rear windows look onto a wall of falling water and a pool that distantly echo Minoan pools and evoke the close connection between Minoan culture and the sea. The deep blue color selected for the gallery's walls likewise evokes the sea and also Minoan wall

\footnotetext{
${ }^{3}$ Picón et al. 2007, 26-8, 38-9, figs. 14-21; 40, fig. 23; 411-12, cat. nos. 14-21, 23.

${ }^{4}$ Chetham 1967.
} 


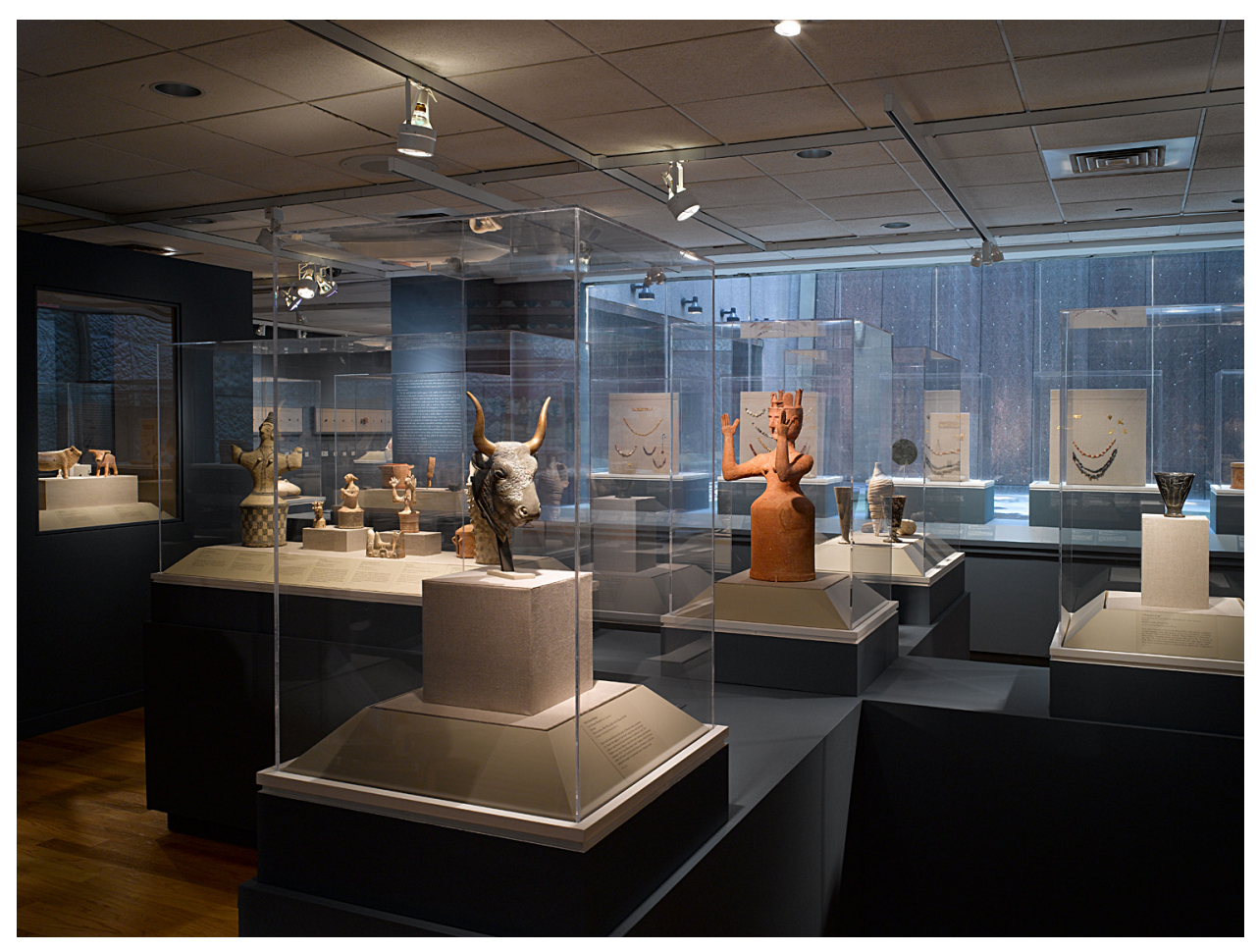

Fig. 1.View of the section,"Religion and Ritual” (J.Coscia, Jr.; @ Onassis Cultural Center; Hellenic Ministry of Culture).

painting. The gallery has low ceilings, recalling Minoan architecture; most extant Minoan artifacts, which are small in scale, could easily have been dwarfed by loftier surroundings. Displayed in this intimate environment, the objects invite contemplation of their form, design, and technique of manufacture. In fact, a glory of the Onassis exhibition is the juxtaposition of finished products of the highest quality with tools used to make them. For those accustomed to looking at historical Greek art, which is so rich in images of people behaving in ways identifiable to modern eyes, the Minoan world might seem remote and obscure. The display of tools humanizes the artifacts, leading one to imagine skilled Minoan artisans at work, artisans whose renown to their contemporaries in the eastern Mediterranean may be inferred from the Ugaritic myth of Kothar-wa-Hasis, their "Hephaistos," or divine craftsman, who lived on Kaphtor, most likely their name for Crete. $^{5}$

As in previous exhibitions at the Onassis Cultural Center, the current show is accompa-

${ }^{5}$ Morris 1992, 93-5.

${ }^{6}$ The proceedings of a symposium to be held in nied by a splendid catalogue that is full of stimulating, up-to-date, and informative entries and is sumptuously illustrated and modestly priced. ${ }^{6}$ Numbers on the object labels conveniently correspond to the catalogue entries. A reference copy of the catalogue is displayed in the vestibule before the gallery's entrance, as are readable site maps of the Mediterranean and Crete; text panels highlight some of the myths surrounding the island and outline its Bronze Age cultural development. Here the visitor can pick up a complimentary brochure, which provides a succinct and well-informed introduction to Minoan culture and society.

The title of the exhibition is well chosen. Most people who have even a casual familiarity with Greek mythology will have heard of the labyrinth, the great maze constructed by Daidalos for the Cretan King Minos of Knossos to house the Minotaur, the half-man, halfbull product of a sexual encounter between the king's wife Pasiphaë and Poseidon (god of the sea) in the form of a bull. In addition, many scholars will recall that the word labrys

September 2008 will be published in a companion volume of essays. 
occurs in classical Caria, of western Anatolia, as the word for double axe, and that labyrinth means "the house [or place] of the double axe." Perhaps labyrinth was a name for the Minoan palace at Knossos itself, where images of double axes and bulls abound, and where a plethora of twisting right-angled corridors so much resembles a maze.

It is thus appropriate that three bronze double axes confront the visitor entering the exhibition: one clearly is utilitarian, and two large, thin ones must originally have been mounted for ceremonial display. ${ }^{7}$ The recurrence of the double axe in bronze and gold (fig. 2) and in vase paintings and ceramic relief acts as a leitmotif throughout the exhibition, offering a familiar touchstone in the face of a seemingly bewildering spectrum of unintelligible symbols and images. A photographic blow-up of the tiny gold double axe from the sacred cave at Arkalochori (see fig. 2) graces the catalogue's back cover. ${ }^{8}$

The visitor then begins to follow a seemingly intentional labyrinthine route laid out by the placement of the cases. This route is achieved by subdividing the main gallery into three areas with a centrally placed, $\Gamma$-shaped bank of adjoining cases containing two-sided, windowlike vitrines (fig. 3). Cases are also placed along the walls, and others are freestanding (see figs. 1, 3, 4). Two well-known reconstructions of Knossos-the Throne Room by Emile Gilliéron, Jr., and the interior facade of the west wing overlooking the central court by Thomas Phanourakis-are mounted on the walls. One of the flat alabastra from the Throne Room depicted in the reconstruction is on display. ${ }^{9}$

The exhibition and catalogue are organized into 11 themes, chosen to illuminate important aspects of Minoan culture as perceived by 20th-/ 21st-century scholars; however, the thematic sequence presented in the exhibition differs from the catalogue. Text panels, placed at a comfortable height, introduce each exhibition section with succinct and informative discussions.

The first thematic section, "Pots and Potters" (see fig. 3), outlines the history of Minoan ceramics, which has always formed the archaeological backbone of Cretan Bronze Age relative

${ }^{7}$ Herakleion Archaeological Museum, inv. nos. HM 2049, 2418, 5829 (Andreadaki-Vlazaki et al. 2008, 240-43, nos. 195-97).

${ }^{8}$ Herakleion Archaeological Museum, inv. no. HM 599 (Andreadaki-Vlazaki et al. 2008, 238-39,

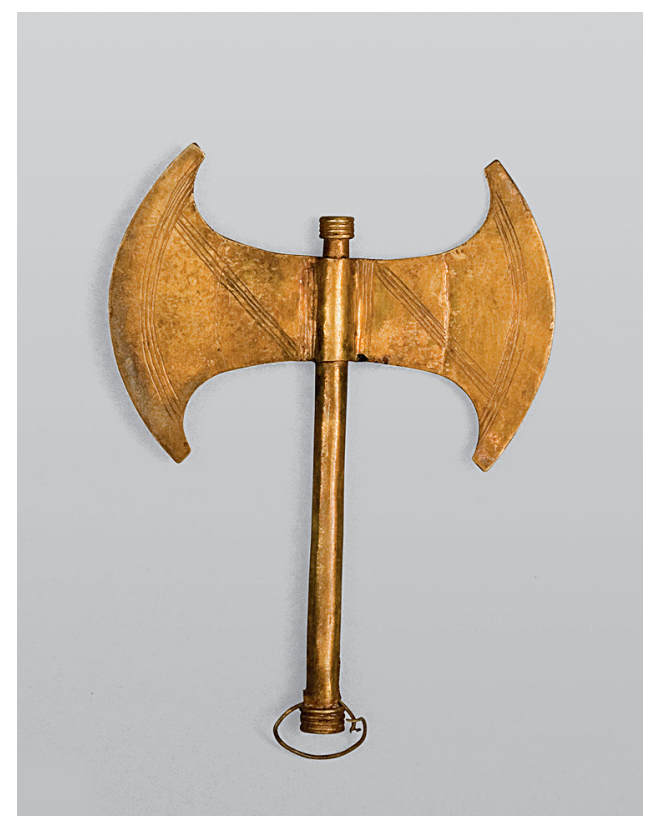

Fig. 2. Gold votive axe from Arkalochori cave, Middle Minoan IIIB (ca. 1650-1600 B.C.E.), Igth. of axe $4.8 \mathrm{~cm}$, Igth. of haft 5.7 $\mathrm{cm}$. Herakleion, Herakleion Archaeological Museum, inv. no. HM 599 (๑ Hellenic Ministry of Culture).

chronology. Based on the stratigraphic contexts of the pottery from the palace at Knossos, which was founded on a Neolithic mound, Evans divided the development of Minoan civilization into a broad tripartite scheme of Early Minoan (EM), Middle Minoan (MM), and Late Minoan (LM), with each period further subdivided into at least three subphases. ${ }^{10}$ The absolute dates for these phases derive primarily from Minoan synchronisms with Egypt. During the 1960s, Nicholas Platon, excavator of the palace at Zakros, proposed a revised chronological system based on the architectural development of Minoan palaces, whose construction, remodeling, and destruction were regarded as seminal events. These periods are known as Prepalatial (EM I-MM IA, ca. 3000-1900 B.C.E.); Protopalatial (MM IB-MM IIB, ca. 1900-1700 B.C.E.); Neopalatial (MM III-LM IB, ca. 1700-1450 B.C.E.); Final Palatial (LM II-IIIA2, ca. 1450-1300 B.C.E.); and Postpalatial (LM IIIB, ca. 1300-1100 B.C.E.).

no. 194).

${ }^{9}$ Herakleion Archaeological Museum, inv. no. HM 884 (Andreadaki-Vlazaki et al. 2008, 268, no. 220).

${ }^{10}$ Evans 1921-1935. 


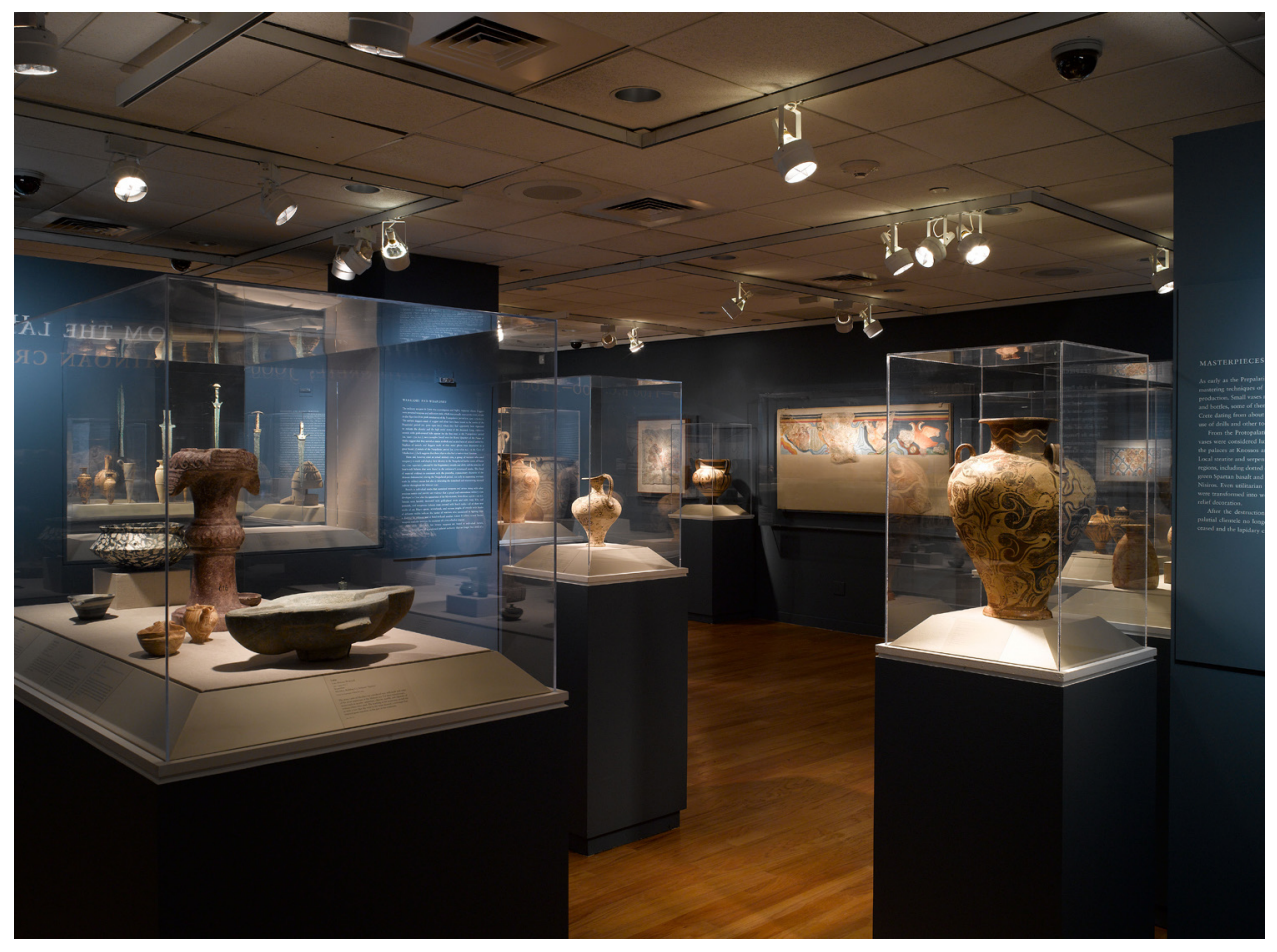

Fig. 3.View of the exhibition's section,"Masterpieces in Stone"; several cases with ceramic vases from the section,"Pots and Potters"; and, on the wall, the Partridge Fresco from the section, "The Colorful World of Murals" (J. Coscia, Jr.; $\odot$ Onassis Cultural Center; Hellenic Ministry of Culture).

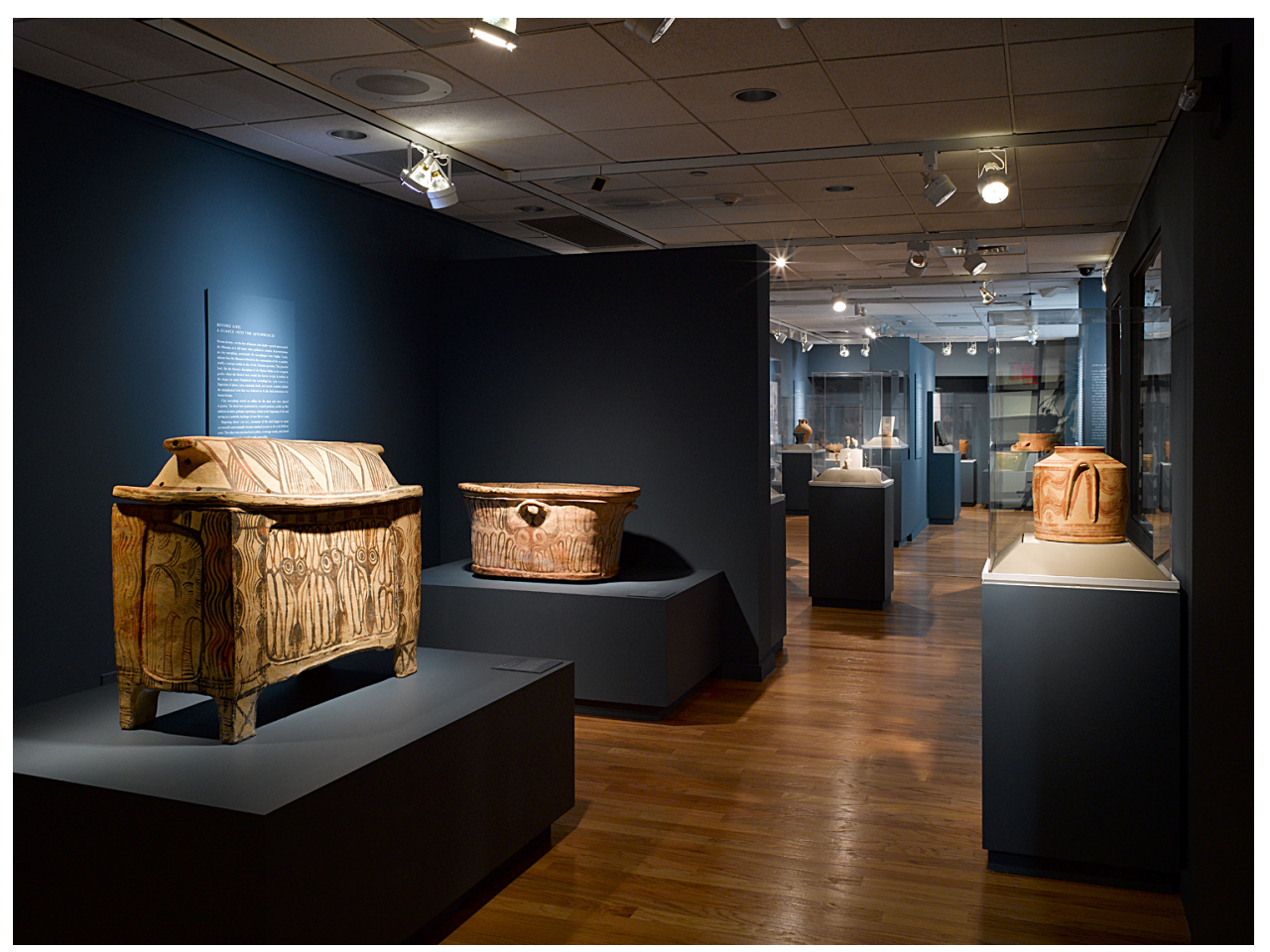

Fig. 4.View of the exhibition's final section, "Beyond Life: A Glance into the Afterworld," and the small back gallery (J. Coscia, Jr; $\odot$ Onassis Cultural Center; Hellenic Ministry of Culture). 
Pottery from the Neolithic and Prepalatial periods is displayed in the first two cases. The wide diversity of ceramic styles made concurrently on Crete during the Early Minoan period -including the elegant Haghios Onouphrios Ware, ${ }^{11}$ with precise linear decoration on a buff ground, and the brilliant mottled Vasiliki Ware, ${ }^{12}$ along with the variety of burial customs-suggests that after the Neolithic era, people migrated to Crete from different regions, probably including western Asia Minor and the Cyclades, and as this reviewer believes, the southern Levant. ${ }^{13}$

Although no vases from the next phases (EM III-MM IA) are exhibited, just prior to the construction of the palaces in MM IB, potters on Crete gradually adopted a uniform whiteon-dark decorative scheme, leading to one of the most vibrant ceramic wares ever created, Protopalatial Kamares Ware, named for the cave on Mount Psiloritis, in which the first large deposit was discovered. This splendid ware is represented by nine specimens of the mature MM II style shown in a somewhat crowded display with a rather dizzying effect. All are covered with a rich, black slip over which an endless variety of white abstract floral and geometric patterns highlighted with red dots and lines swirl with seemingly effortless yet controlled abandon. ${ }^{14}$

It is enlightening to examine the two potter's wheels on display, a hand-turned specimen from the EM settlement of Myrtos / Phournou Koriphi, and a kick-turned one from Neopalatial Mochlos. ${ }^{15}$ These wheels document one of the most significant technological developments in the potter's craft, the change from a slow to a fast-turning wheel.

After another earthquake at the end of MM III, Minoan civilization reached its apogee during the mature phases of the Neopalatial period (LM IA, ca. 1600-1500 B.C.E., and LM IB, ca. 1500-1450 B.C.E.), contemporary with

${ }^{11}$ Herakleion Archaeological Museum, inv. no. HM 10853 (Andreadaki-Vlazaki et al. 2008, 23, no. 2).

${ }^{12}$ Haghios Nikolaos Archaeological Museum, inv. nos. 7214, 7224 (Andreadaki-Vlazaki et al. 2008, 31-2, nos. 10, 11).

${ }^{13}$ Andreadaki-Vlazaki et al. 2008, 15.

${ }^{14}$ Herakleion Archaeological Museum, inv. nos. HM 5833, 5834, 5836, 10089, 10162, 10198, 10594, 10606, 18593 (Andreadaki-Vlazaki et al. 2008, 339, 41-2, nos. 12-18, 20-1).

${ }^{15}$ Haghios Nikolaos Archaeological Museum, inv. nos. 6957, 14409 (Andreadaki-Vlazaki et al.
Egypt's grand 18th Dynasty. These two periods are divided by yet another earthquake, probably one triggered by the catastrophic volcanic eruption on the Cycladic island of Thera (modern Santorini), north of Crete. Indeed, it is widely thought that the eruption of the Theran volcano, at the end of LMIA, weakened Crete, covering its eastern end with a layer of volcanic ash, interrupting its agricultural cycle, and thereby setting the stage for conquest of the island at the end of LM IB by the Mycenaeans, a contemporaneous warlike people of the Greek mainland.

For many visitors, the ceramic section's highlight will be vases made during LM IB, the last truly "Minoan" era, before the arrival of Greek-speaking Mycenaeans. A stirrup jar from Gournia-whose diagonally poised octopus appears to embrace the pot's squat, globular body with its tentacles-is a masterpiece of the Marine Style, one of Philip P. Betancourt's Special Palatial Tradition dark-on-light style vases, which underscore the Minoans' affinity with nature and, particularly, with the sea. ${ }^{16}$

Nestled among these ceramic cases, the single case housing the thematic section "Masterpieces in Stone" contains some of the most attractive Minoan stone vases extant. Created long before the discovery of iron, they were drilled and carved with copper, bronze, and obsidian tools and polished with emery and quartz. ${ }^{17}$ One marvels at the refined little Prepalatial marble vases from the Mochlos cemetery, which skillfully exploit the stones' veining for their decorative surface effects. ${ }^{18}$

Three fragmentary wall paintings displayed on the right-hand wall comprise the section "The Colorful World of Murals" (see fig. 3). Pride of place goes to the famous restored Partridge Fresco from the Neopalatial Caravanserai at Knossos, originally painted as a frieze along the top of a wall. ${ }^{19}$ The beautiful fragmentary relief wall painting from Knossos

2008, 29, 47, nos. 8, 26).

${ }^{16}$ Herakleion Archaeological Museum, inv. no. HM 2783 (Andreadaki-Vlazaki et al. 2008, 54, no. 32; Betancourt 1985, 140-47).

${ }^{17}$ Evely 1993, 172-94.

${ }^{18}$ Herakleion Archaeological Museum, inv. nos. HM 1204, 1237, 1246, 1255, 2395; Haghios Nikolaos Archaeological Museum, inv. no. 280 (Andreadaki-Vlazaki et al. 2008, 68-73, nos. 43-8).

${ }^{19}$ Herakleion Archaeological Museum, inv. no. HM 13 (Andreadaki-Vlazaki et al. 2008, 192, 19697, no. 158). 
of an olive tree, ${ }^{20}$ dated to MM IIIA, which is one of the earliest figural wall paintings from Crete, attests to a burgeoning interest in representational art, particularly floral depictions, at the start of the Neopalatial era. Another fragmentary painting from a house at Zakros, dated to LM I, depicts lozenges linked by rosettes and filled with stylized red lily-papyrus hybrids. ${ }^{21}$ This repeated pattern may well have been inspired by woven or embroidered textiles, familiar from their depiction in Aegean wall paintings. ${ }^{22}$ It is a rare treat to be able to examine these restored frescoes up close at eye level; the viewer can thereby appreciate the delicacy and naturalism of the brush strokes on the preserved original fragments.

Although many questions still surround the presence of the Mycenaeans on Crete, the discovery of Linear B (the script used by Mycenaeans to write Greek) on tablets in the palaces at Knossos and Khania is evidence that the island must have fallen under their control. ${ }^{23}$ This era, known as the Final Palatial, covers the ceramic phases LM II-LH IIIA2 (ca. 1450-1300 B.C.E.), during which Mycenaeans may have ruled from palaces at Knossos and Khania and perhaps at Haghia Triada.

Linear B is not the only evidence for Mycenaeans on Crete. Among the numerous changes in the island's material culture after ca. 1450, changes in art may be eloquently observed by comparing the Marine Style octopus stirrup jar from Gournia ${ }^{24}$ with a Postpalatial stirrup jar from Khania painted with a vertical stylized octopus, whose tentacles are rendered as a pattern of parallel wavy bands. ${ }^{25}$

The LM II pithoid jar from the Katsambas cemetery decorated with boar's tusk helmets ${ }^{26}$ provides a logical transition to the section entitled "Warriors and Weaponry," which is dominated by finds from the Final and Post-

${ }^{20}$ Herakleion Archaeological Museum, inv. no. HM 36A (Andreadaki-Vlazaki et al. 2008, 194-95, no. 157).

${ }^{21}$ Siteia Archaeological Museum, inv. no. 13317 (Andreadaki-Vlazaki et al. 2008, 198-99, no. 159).

${ }^{22}$ E.g., Immerwahr 1990, pl. 18.

${ }^{23}$ Herakleion Archaeological Museum, inv. nos. HM 107, 115 (Andreadaki-Vlazaki et al. 2008, 139, nos. 107A, 107B).

${ }^{24}$ Supra n. 18.

${ }^{25}$ Haghios Nikolaos Archaeological Museum, inv. no. 135 (Andreadaki-Vlazaki et al. 2008, 63, no. 41 ).

${ }^{26}$ Herakleion Archaeological Museum, inv. no. HM 10058 (Andreadaki-Vlazaki et al. 2008, 111, palatial periods on Crete. Although several long swords are known from the Protopalatial era and a "military elite" has been postulated from the remains of swords, dirks, and boar's tusk helmets discovered in the Neopalatial burials of the Poros cemetery outside Herakleion, ${ }^{27}$ prior to the Final Palatial era, weapons and military imagery are relatively rare in Minoan material culture. A double-sided windowlike vitrine in the central bank of cases (see fig. 3) arrestingly displays bronze weaponry, including a long bronze sword with its preserved ivory pommel and gold rivets, recently discovered in a warrior grave from the Final Palatial cemetery at Khania, and a typically Mycenaean short-sword, or dirk, with preserved ivory hilt plates from Chamezi, near Siteia. ${ }^{28}$ Visitors will surely enjoy seeing an actual boar's tusk helmet, ${ }^{29}$ from the LM IIIA-B Armenoi cemetery, alongside a bone appliqué from the Khania cemetery with a rare depiction of a warrior's head en face wearing a boar's tusk helmet. ${ }^{30}$

The back right corner of the gallery contains an impressive open display of large-scale ceramic vessels. The grand double axe in relief on a pithos from Zakros may hint at the special significance of the vase's original contents, ${ }^{31}$ and this potent symbol brings to mind the ubiquity of imagery, artifacts, and architectural spaces that seem to be related to cult and religion in Minoan culture.

Indeed, the heart of the current show belongs to the centrally located section, entitled "Religion and Ritual Practice" (see fig. 1 ), which displays some of the most famous examples of Minoan art. This important section is subdivided into four categories: divine, figurines, music, and ritual equipment. The first case contains examples of the so-called rhyton, named for its similarity to a vessel

no. 83).

${ }^{27}$ Andreadaki-Vlazaki et al. 2008, 99.

${ }^{28}$ Khania Archaeological Museum, inv. no. M 862; Haghios Nikolaos Archaeological Museum, inv. no. 3099 (Andreadaki-Vlazaki et al. 2008, 102$3,105$, nos. 75,77$)$.

${ }^{29}$ Rethymnon Archaeological Museum, inv. no. O 266 (Andreadaki-Vlazaki et al. 2008, 108, no. 80).

${ }^{30}$ Khania Archaeological Museum, inv. no. K 114 (Andreadaki-Vlazaki et al. 2008, 98, 109, no. 81).

${ }^{31}$ Siteia Archaeological Museum, inv. no. 9973 (Andreadaki-Vlazaki et al. 2008, 56, no. 34). 
from the Classical era of Near Eastern origin, which is perforated at one end so that liquid can flow through it. Rhyta first appear in the Prepalatial era and persist in Aegean Bronze Age culture until the end of the 13th century B.C.E. ${ }^{32}$ Two types are displayed here. The Type II Ovoid (with a narrow mouth opening and a narrow, rounded, perforated tip) is represented by two marvelous Marine Style vases and two fine Neopalatial stone specimens. ${ }^{33}$ The Type III Conical (with a wide mouth opening and a pointed, perforated tip) is represented by a splendid Neopalatial veined limestone specimen and a Final Palatial ceramic one. ${ }^{34}$ These last rhyta would have had a tuft of wool placed inside. When ground aromatics were sprinkled on the wool and wine was poured through the mouth, a flavor-enhanced beverage would have streamed out through the tip.

The "Religion and Ritual Practice" section also presents the so-called horns of consecration, which, together with the double axe, were probably the most important symbols of Minoan religion. Often depicted on the roofs of buildings, the horns may have functioned as an emblem denoting sacred space, although their precise meaning remains elusive. While generally thought to be a stylized representation of the horns of the bull, an animal that held special status in Minoan culture, the horns of consecration may also derive from the Egyptian hieroglyph denoting the horizon. ${ }^{35}$ Multiple horns are featured on the fascinating but not well-known, small Protopalatial plaster model with rectangular protrusions that resemble doors. ${ }^{36}$ This reviewer suggests that the model, which was discovered at the Petsophas peak sanctuary, is actually a model of the Minoan building on Petsophas constructed largely of plaster.

${ }^{32}$ For the types of rhyta, their mechanical functions, contexts, and uses, see Koehl 2006.

${ }^{33}$ Herakleion Archaeological Museum, inv. nos. HM 1126, 2085, 3041, 5408 (Andreadaki-Vlazaki et al. 2008, 256-59, nos. 210-13).

${ }^{34}$ Herakleion Archaeological Museum, inv. nos. HM 336, 2493 (Andreadaki-Vlazaki et al. 2008, 255, 260, nos. 209, 214).

${ }^{35}$ MacGillivray 2000, 129.

${ }^{36}$ Haghios Nikolaos Archaeological Museum, inv. no. 6805 (Andreadaki-Vlazaki et al. 2008, 247, no. 201).

${ }^{37}$ Herakleion Archaeological Museum, inv. no. HM 2713 (Andreadaki-Vlazaki et al. 2008, 236, 250-51, no. 205).

${ }^{38}$ Koehl 2006, 33-5.
One exhibition highlight is a masterpiece of Minoan stone carving: the chlorite Type II bull's head rhyton from the LM IB destruction level of the palace at Zakros (see fig. 1), whose image graces the catalogue's front cover. ${ }^{37}$ Bulls are the most common species of animal headshaped rhyton, and the one from Zakros is the finest of all. While its horns-probably originally made of gold foil-covered wood-are entirely restored, the similarity of its profile and freeflowing locks of hair to the silver Type II bull's head rhyton from Shaft Grave IV at Mycenae and a fragmentary clay one from Akrotiri on Thera suggest it was carved in LM IA. ${ }^{38}$

The small Neopalatial steatite chalice known as the Chieftain Cup has always been difficult to see in the Herakleion Archaeological Museum, but this exhibition's lighting allows one to appreciate fully the fine details of the two young men on the front, including their musculature, costumes, and hairstyles, and to examine the heavily restored back, with its procession of oxhide-bearing youths. ${ }^{39}$ While its iconographic interpretations vary widely, this reviewer has interpreted the imagery as a reference to a coming of age ritual in which the initiate is presented with military equipment and, perhaps, the actual cup. ${ }^{40}$

Two of the cases of ritual paraphernalia are devoted primarily to Final Palatial and Postpalatial wheelmade terracotta female figures and figurines (see fig. 1). While some may arguably be identified as divinities-for example, the one who holds up a small male figure and may thus be a kourotrophos (divine protectress of children $)^{41}$ and those wearing headdresses who raise their arms, perhaps in a gesture of benediction ${ }^{42}$ - another with clasped hands suggests a worshiper in prayer. ${ }^{43}$

\footnotetext{
${ }^{39}$ Herakleion Archaeological Museum, inv. no. HM 341 (Andreadaki-Vlazaki et al. 2008, 206, no. 163).

${ }^{40}$ Koehl 1986.

${ }^{41}$ Herakleion Archaeological Museum, inv. no. HM 8345 (Andreadaki-Vlazaki et al. 2008, 207, no. 164).

${ }^{42}$ Herakleion Archaeological Museum, inv. no. HM 3861; Rethymnon Archaeological Museum, inv. no. П 637; Herakleion Archaeological Museum, inv. no. HM 9308 (Andreadaki-Vlazaki et al. 2008, 202, 210-13, nos. 167-69).

${ }^{43}$ Haghios Nikolaos Archaeological Museum, inv. no. 1860 (Andreadaki-Vlazaki et al. 2008, 209, no. 166).
} 
Gold artifacts with ritual connotations are displayed in another case. The tiny MM IIIB double axe from the Arkalochori cave (see fig. 2 ) is engraved with parallel lines forming a zigzag motif, similar to those on the ceremonial bronze double axes at the exhibition's entrance. ${ }^{44}$ It may originally have been worn as a pendant, suspended from its gold wire loop, before being left as a votive.

Two small Neopalatial gold signet rings represent a class of Minoan material culture that preserves some of the most compelling extant images related to cult and ritual practices. A well-known example from the Kalyvia cemetery at Phaistos depicts several activities familiar from this class, including a male kneeling over a baetyl (sacred stone). ${ }^{45}$ The second ring is displayed here for the first time since its discovery in the sanctuary at Kato Syme in $2000 .{ }^{46}$ Known as the Runner's Ring, this signet has a hitherto unattested depiction of a runner, which this reviewer would argue is related to an age-grade initiation in Minoan culture that continued into the post-Bronze Age era. ${ }^{47}$ Texts from classical Crete call a youth a dromeus (runner) after he has won a footrace and planted a tree and has thus successfully graduated from the agela, or herd (one of the groups into which Cretan boys were divided). My one criticism of this display is the use of drawings alone to illustrate the intaglios without the aid of modern impressions, which more accurately communicate the artists' intentions.

In the context of ritual, a fragmentary plaster leg of a tripod table from Palaikastro decorated like a wall painting with narcissus flowers emerging from a black-and-blue striped flower pot is a striking recently discovered

\footnotetext{
${ }^{44}$ Supra n. 7.

${ }^{45}$ Herakleion Archaeological Museum, inv. no. HM 45 (Andreadaki-Vlazaki et al. 2008, 203, no. 160).

${ }^{46}$ Herakleion Archaeological Museum, inv. no. HM 1699 (Andreadaki-Vlazaki et al. 2008, 204, no. 161). 2000 .

${ }^{47}$ The author's views are summarized in Koehl

${ }^{48}$ Siteia Archaeological Museum, inv. no. 11365 (Andreadaki-Vlazaki et al. 2008, 237, no. 193).

${ }^{49}$ Immerwahr 1990, 180 (Am No. 2), 187 (Ak No. 10).

${ }^{50}$ Siteia Archaeological Museum, inv. no. 6206; Herakleion Archaeological Museum, inv. no. HM 5413 (Andreadaki-Vlazaki et al. 2008, 252-53, nos. 206, 207)

${ }^{51}$ E.g., Khania Archaeological Museum, inv. no.
}

object. ${ }^{48}$ This painted leg recalls depictions of lilies growing from low planters at Amnissos and from tall pots at Akrotiri, ${ }^{49}$ although, as is often the case, the significance of this practice in Minoan culture remains obscure.

An embedded vitrine with ritual paraphernalia contains two ceramic Type I figural bull rhyta: a somewhat stiff, hand-modeled MM IB specimen and a more naturalistically rendered LM IB moldmade example from Pseira. ${ }^{50}$ Both are painted with patterns that may plausibly be interpreted as hunting nets. Bull grappling, perhaps part of bull hunts on Crete, may have been the first step in the development of bullleaping acrobatics - one of the most distinctive activities depicted in Minoan art. ${ }^{51}$

The role of music in Minoan cult has been surmised from depictions on several wellknown objects, including the LM IIIB (Postpalatial) pyxis with a lyre..$^{52}$ A small case displays actual musical instruments: a recently discovered MM I-II clay sistrum, or rattle, from Haghios Charalampos, ${ }^{53}$ probably a funerary gift, and an LM IB bronze sistrum from Mochlos. ${ }^{54}$

The most outstanding ritual object in another small case is the famous alabaster model of a triton shell from the Central Palace sanctuary at Knossos, which was most likely a libation vessel..$^{55}$ Against the right wall is a display of 20 conical clay cups, numerically and contextually the single most common class of Minoan artifact. ${ }^{56}$ Discovered recently in a deposit that included thousands more plus cooking paraphernalia and animal bones, these conical cups thus provide convincing evidence that, in addition to libation, communal dining figured among Minoan ritual or ceremonial activities. Other artifacts in this case include the famous

KH 1547 (Andreadaki-Vlazaki et al. 2008, 152, no. 117; see also Koehl 2006, 328-29).

${ }^{52}$ Khania Archaeological Museum, inv. no. P 2308 (Andreadaki-Vlazaki et al. 2008, 232, 235, no. 192).

${ }^{53}$ Haghios Nikolaos Archaeological Museum, inv. no. 13976 (Andreadaki-Vlazaki et al. 2008, 234, no. 191).

${ }^{54}$ Haghios Nikolaos Archaeological Museum, inv. no. 14398 (Andreadaki-Vlazaki et al. 2008, 233, no. 190).

${ }^{55}$ Herakleion Archaeological Museum, inv. no. HM 45 (Andreadaki-Vlazaki et al. 2008, 254, no. 208).

${ }^{56}$ Kissamos Archaeological Museum, inv. nos. P 765-84 (Andreadaki-Vlazaki et al. 2008, 269, no. 221). 
Final Palatial beaked jug from the Little Palace at Knossos with relief decoration, including the so-called Sacral Knot motif, ${ }^{57}$ and two Final or Postpalatial composite vessels decorated with plastic and painted birds, believed by some to symbolize epiphany. ${ }^{58}$

The section entitled "Jewels for Life and Death," arranged against the back wall of the main gallery, directly in front of the pool, is truly a visual delight. The gold cut-out, floralshaped ornaments and geometric decorated bands from EM II-III burials at Mochlos recall, albeit on a smaller scale, the roughly contemporary gold hair ornaments from the Royal Cemetery at Ur. ${ }^{59}$ Gold next occurs prominently on Crete in burials of the Final Palatial era, which contained moldmade hollow gold beaded necklaces and diadems. ${ }^{60}$ The Minoan love of color is reflected in beaded necklaces made from a variety of stones carved in a wide range of shapes. The earliest on display come from the Prepalatial tholos tombs of the Mesara, ${ }^{61}$ followed by examples from Final Palatial burials. ${ }^{62}$ A large 12th-century gold ring skillfully decorated with granulation-one of the latest artifacts on display-demonstrates that goldsmiths continued to practice their trade with consummate skill more than a century after the collapse of palatial society on Crete. ${ }^{63}$

The exhibition's small back gallery alongside the fountain court is divided by a central bank of cases into two narrow spaces that

${ }^{57}$ Herakleion Archaeological Museum, inv. no. HM 5749 (Andreadaki-Vlazaki et al. 2008, 270-71, no. 222).

${ }^{58}$ Khania Archaeological Museum, inv. no. П 6339; Haghios Nikolaos Archaeological Museum, inv. no. 1973 (Andreadaki-Vlazaki et al. 2008, 27273, nos. 223-24).

${ }^{59}$ Herakleion Archaeological Museum, inv. nos. HM 260-61, 287, 289, 325-26 (Andreadaki-Vlazaki et al. 2008, 166, 168-69, nos. 131-33; see also Zettler and Horne 1998, 89-92, no. 29).

${ }^{60}$ Herakleion Archaeological Museum, inv. nos. HM 206, 1037; Khania Archaeological Museum, inv. no. M 497 $\alpha-1$ (Andreadaki-Vlazaki et al. 2008, 172-74, nos. 136, 137, 139A)

${ }^{61}$ Herakleion Archaeological Museum, inv. nos. HM 1151, 1229 (Andreadaki-Vlazaki et al. 2008, 170-71, nos. 134-35).

${ }^{62}$ Herakleion Archaeological Museum, inv. nos. HM 239, 1335; Rethymnon Archaeological Museum, inv. no. $\Lambda$ 731, 735 (Andreadaki-Vlazaki et al. 2008, 176-79, nos. 140-43).

${ }^{63}$ Herakleion Archaeological Museum, inv. no. HM 765 (Andreadaki-Vlazaki et al. 2008, 181, no. 145).

${ }^{64}$ Rethymnon Archaeological Museum, inv. nos. O 330, 361, 376, 384, 557 (Andreadaki-Vlazaki house four interesting thematic sections (fig. 4), whose artifacts bring us particularly close to the people who made and used the objects in this exhibition. The first section, "In the Domain of the Craftsman," presents a selective diachronic outline of the development of Minoan tools, including a group of Neolithic bone awls from the Gerani cave near Rethymnon; ${ }^{64}$ five elegant EM I-IIA imported Melian obsidian blades from the Haghia Photia cemetery; ${ }^{65}$ beautifully preserved bronze tools from Protopalatial (MM II) Quartier Mu at Malia, ${ }^{66}$ Neopalatial (LM IB) Mochlos, ${ }^{67}$ and Postpalatial (LM IIIA-B) Lasithi and Armenoi. ${ }^{68}$ Clay molds for bronze handles from LM IB Mochlos also document Minoan technology. ${ }^{69}$ In the central case, two imported Cypriot copper oxhide-shaped ingots found at Mochlos provide unambiguous evidence for one source of copper and document Minoan involvement in international trade during the Neopalatial period..$^{70}$

Indeed, the lack of copper on Crete may well have stimulated the development of agriculture-based industries that could produce commodities worthy of being traded. Such a scenario may be inferred from the artifacts displayed against the back room's left wall, in its second thematic section, "Alimentation and Aromatics," including a wine press and vat that are displayed together, as they would have been used; ${ }^{71}$ a cooking pot with a fire-box lid; ${ }^{72}$ a miniature cup whose residue was analyzed

et al. 2008, 80-1, nos. 53A-E).

${ }^{65}$ Haghios Nikolaos Archaeological Museum, inv. nos. $332 \alpha \tau, 2673 i \eta, 3523 \varepsilon, 4142 \xi, 26821 \beta$, (Andreadaki-Vlazaki et al. 2008, 82, no. 54).

${ }^{66}$ Haghios Nikolaos Archaeological Museum, inv. nos. 13445, 14380, 14381 [3066] (AndreadakiVlazaki et al. 2008, 83-4, nos. 55-7).

${ }^{67}$ Haghios Nikolaos Archaeological Museum, inv. nos. 14395-97, 14399, 14400, 14401 (Andreadaki-Vlazaki et al. 2008, 78, 84-7, nos. 58, 59A, 59B, 60, 61A, 61B).

${ }^{68}$ Haghios Nikolaos Archaeological Museum, inv. no. 1866; Rethymnon Archaeological Museum, inv. no. M 452 (Andreadaki-Vlazaki et al. 2008, 87-8, nos. 62-3).

${ }^{69}$ Haghios Nikolaos Archaeological Museum, inv. nos. 14392, 14393 (Andreadaki-Vlazaki et al. 2008, 94, nos. 69A, 69B).

${ }^{70}$ Haghios Nikolaos Archaeological Museum, inv. nos. 14388, 14389 (Andreadaki-Vlazaki et al. 2008, 89-90, nos. 64, 65).

${ }^{71}$ Siteia Archaeological Museum, inv. nos. 2462, 13316 (Andreadaki-Vlazaki et al. 2008, 118-19, nos. 87-8).

${ }^{72}$ Rethymnon Archaeological Museum, inv. no. П 2338 (Andreadaki-Vlazaki et al. 2008, 126, no. 96). 
and found to contain iris oil (apud alia) $;^{73}$ and a beekeeping vessel (smoker) ${ }^{74} \mathrm{~A}$ beautiful LM II strainer pyxis with its lid intact (fig. 5), standing in its own case, was perhaps used in perfume manufacture for drying aromatic herbs or flowers. It is decorated with running spirals and flowers, such as lilies, in a style that seems to bridge the Neo- and Final Palatial eras. ${ }^{75}$ The display of terracotta cooking pots, ${ }^{76}$ a grater, shells, carbonized peas, and carbonized figs ${ }^{77}$ takes us inside the Minoan kitchen and gives us a glimpse of their diet.

The third section here, "Scripts and Weights," which illuminates the world of Minoan scribes and merchants, begins with a Protopalatial seal inscribed with hieroglyphic signs, the earliest script widely circulated on Bronze Age Crete. ${ }^{78}$ By the Neopalatial period, not only tablets and roundels but also stone vessels and tables, probably used in ritual, were inscribed in the newly developed Linear A script, which today is still mostly undeciphered. ${ }^{79}$ Two cases collect evidence for writing: Linear A tablets that record transactions relating to various commodities $^{80}$ and four clay seal-impressed and Linear A-inscribed LM IB roundels from Khania, which were receipts for delivered goods, ${ }^{81}$ two Linear B tablets relating to flocks and grain;, 82 and a stirrup jar with a Linear B dipinto used for shipping wine and oil. ${ }^{83}$

In the fourth section, "Seal Engraving: Great Art in Miniature," placed along the left-hand wall near the entrance of the small back gallery, the visitor is treated to a diachronic display outlining the development of seal carving from the Prepalatial to Final Palatial eras, EM II-LM IIIA. These wondrous glyptic objects, used for adornment, personal identification, and guaranteeing business transactions, are made in a range of materials including bone,

${ }^{73}$ Rethymnon Archaeological Museum, inv. no. П 15307 (Andreadaki-Vlazaki et al. 2008, 123, no. 94).

${ }^{74}$ Herakleion Archaeological Museum, inv. no. HM 2113 (Andreadaki-Vlazaki et al. 2008, 117, no. 86).

${ }^{75}$ Rethymnon Archaeological Museum, inv. no. П 2337 (Andreadaki-Vlazaki et al. 2008, 114, 12425, no. 95).

${ }^{76}$ Haghios Nikolaos Archaeological Museum, inv. no. 8627; Khania Archaeological Museum, inv. nos. П 4485, 4486 (Andreadaki-Vlazaki et al. 2008, 120-21, nos. 89, 90A, 90B).

${ }_{77}$ Rethymnon Archaeological Museum, no inv. no.; Khania Archaeological Museum, no inv. nos. (Andreadaki-Vlazaki et al. 2008, 122-23, nos. 91-3).

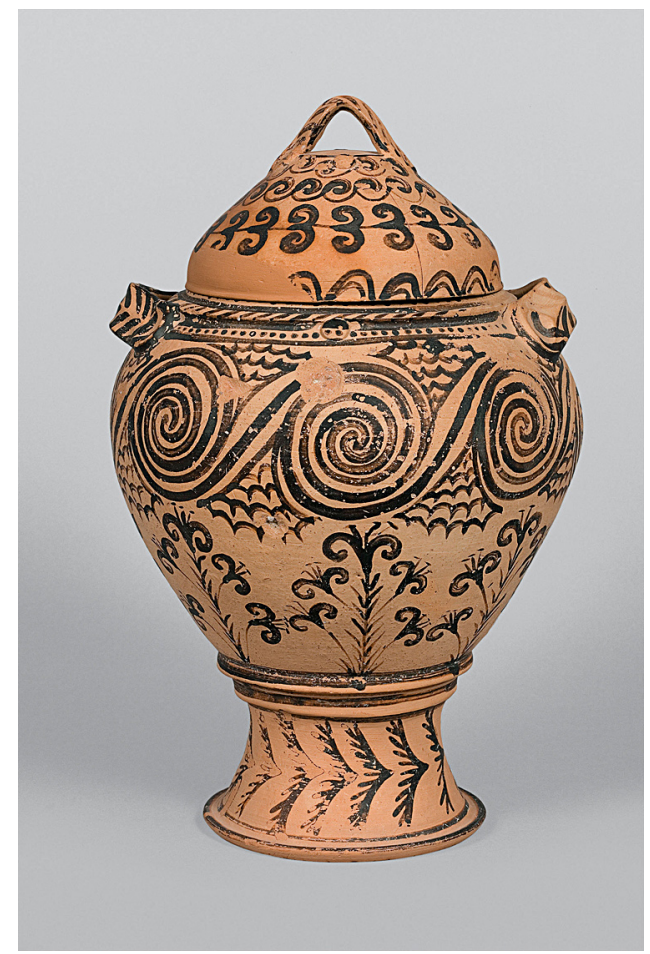

Fig.5.Ceramic strainer pyxis from Stavromenos-Khamalevri. Rethymnon, Rethymnon Archaeological Museum, inv. no. 2337. Late Minoan II (ca. 1450-1400 B.C.E), ht. (with lid) 40.8 $\mathrm{cm}$ (๑ Hellenic Ministry of Culture).

hippopotamus tusk, and colorful semiprecious stones. By the Neopalatial era, Minoan seals, with their figural imagery, especially animals in motion, may justifiably be described as masterpieces in miniature. Seals, however, are difficult to exhibit, and the display is disappointing. When placed against a solid background, they seem to be merely dark circles with distracting veins. Perhaps seals made from translucent

${ }^{78}$ Herakleion Archaeological Museum, inv. no. HM 1883 (Andreadaki-Vlazaki et al. 130, no. 98).

${ }^{79}$ Herakleion Archaeological Museum, inv. nos. HM 1341, 1545 (Andreadaki-Vlazaki et al. 2008, 131, nos. 99, 100).

${ }^{80}$ Siteia Archaeological Museum, inv. nos. 1619, 1627; Khania Archaeological Museum, inv. nos. KH 5, 7 (Andreadaki-Vlazaki et al. 2008, 132-34, nos. 101A, 101B, 102A, 102B).

${ }^{81}$ Khania Archaeological Museum, inv. nos. KH 2002, 2030, 2055, 2117 (Andreadaki-Vlazaki et al. 2008, 135-38, nos. 103-6).

${ }^{82}$ Supra n. 23.

${ }^{83}$ Khania Archaeological Museum, inv. no. П 10344 (Andreadaki-Vlazaki et al. 2008, 140, no. 108). 
stones could be displayed with back lighting. Certainly, as already mentioned in regard to signet rings, seals should be displayed with modern impressions, which is the best way to see their images and to appreciate their subtly modeled surfaces. Ironically, the little lumps of fire-hardened stamped clay sealings, which reveal the three-dimensional quality of these now-lost splendid carved creations, comprise the most appealing part of this display. ${ }^{84}$ This exhibition's single visual reference to the bull acrobatics closely associated with Minoan culture is found on a clay sealing from Khania with a particularly muscular bull and a slender leaper caught in dismount. ${ }^{85}$

Upon leaving the small back gallery, one returns to the world of ritual for a display of figurines, which includes terracottas from four peak sanctuaries: Petsophas, Piskokephalo, Prinias, and Vrysinas. Their surfaces are worn and lack traces of paint because they were left as votives either out in the open or in rock crevices. While young males are represented at Petsophas, ${ }^{86}$ females predominate, with examples from each sanctuary. The billowing garment worn by one female from Prinias ${ }^{87}$ and the extravagant bouffant coiffures worn by two from Piskokephalo are notable. ${ }^{88} \mathrm{Hu}$ man body parts from Petsophas, perforated for suspension, recall the traditional Greek tamata (metal talismans of body parts attached to icons in Orthodox churches), ${ }^{89}$ while the bovids and bird from Vrysinas ${ }^{90}$ and the beetle from Piskokephalo imply other concerns of Minoan worshipers. ${ }^{91}$

The exhibition's final section is appropriately entitled "Beyond Life: A Glance into the Afterworld." Here, three 13th-century terracotta sarcophagi, or larnakes, are displayed without cases. The legs and recessed fronts and

${ }^{84}$ Rethymnon Archaeological Museum, inv. no. П 7577, 7581; Khania Archaeological Museum, inv. no. KH 1561 (Andreadaki-Vlazaki et al. 2008, 150, 153, nos. 115A, 115B, 118); supra n. 51.

${ }^{85}$ Supra n. 51.

${ }^{86}$ Haghios Nikolaos Archaeological Museum, inv. nos. 9953, 9955 (Andreadaki-Vlazaki et al. 2008, 222-23, nos. 177, 178).

${ }^{87}$ Haghios Nikolaos Archaeological Museum, inv. no. 6028 (Andreadaki-Vlazaki et al. 2008, 217, no. 172).

${ }^{88}$ Herakleion Archaeological Museum, inv. nos. HM 9735, 9823 (Andreadaki-Vlazaki et al. 2008, 214, 220-21, nos. 175, 176).

${ }^{89}$ Haghios Nikolaos Archaeological Museum, inv. nos. 5962, 6079, 10586; Herakleion Archaeo- sides of the so-called chest-shaped larnakes may have been inspired by wood versions. ${ }^{92}$ There is also a bathtub-shaped larnax, whose marine-inspired decoration, both inside and out, suggests its association with the sea. ${ }^{93}$ This vessel must have served either as an actual bathtub or as a container for a metaphorical afterlife journey. The depictions of double axes rising from horns of consecration on both chestshaped larnakes bring us full circle by reminding the viewer of these symbol-laden images' power. It is not known, however, whether they retained their original meanings or changed along with other political and social developments that affected the island of Crete at the end of the Neopalatial era.

Either before exiting the Olympic Tower or before viewing the show, visitors should examine the 10 stunningly beautiful aerial photographs of Minoan archaeological sites in large gelatin silver prints by award-winning photographer Marilyn Bridges exhibited in the building's lobby. Fine works of art in their own right, they remind the viewer of the contexts from which derive many of the great works exhibited in the gallery on the floor below with such care and intelligence.

DEPARTMENT OF CLASSICAL AND ORIENTAL STUDIES

HUNTER COLLEGE

THE CITY UNIVERSITY OF NEW YORK

695 PARK AVENUE

NEW YORK, NEW YORK 10021

RKOEHL@HUNTER.CUNY.EDU

\section{Works Cited}

Betancourt, P.P. 1983. The Cretan Collection in the University Museum, University of Pennsylvania. Vol. 1, Minoan Objects Excavated from Vasilike,

logical Museum, inv. nos. HM 3443, 3448 (Andreadaki-Vlazaki et al. 2008, 226-27, nos. 181-83A, 183B, 184).

${ }^{90}$ Rethymnon Archaeological Museum, inv. nos. П 7590, 7592, 23672, 24927 (AndreadakiVlazaki et al. 2008, 228-30, nos. 185-88).

${ }^{91}$ Herakleion Archaeological Museum, inv. no. HM 9796 (Andreadaki-Vlazaki et al. 2008, 231, no. 189).

${ }_{92}$ Rethymnon Archaeological Museum, inv. nos. П 1703, 1710 (Andreadaki-Vlazaki et al. 2008, 276-79, nos. 225, 226).

${ }^{93}$ Haghios Nikolaos Archaeological Museum, inv. no. 262 (Andreadaki-Vlazaki et al. 2008, 274, $280,227)$. 
Pseira, Sphoungaras, and Other Sites. University Museum Monograph 51. Philadelphia: University of Pennsylvania Museum of Archaeology and Anthropology.

. 1985. The History of Minoan Pottery. Princeton: Princeton University Press.

Betancourt, P.P., and J.S. Silverman. 1991. The Cretan Collection in the University Museum, University of Pennsylvania. Vol. 2, Pottery from Gournia. University Museum Monograph 72. Philadelphia: University of Pennsylvania Museum of Archaeology and Anthropology.

Chetham, C. 1967. A Land Called Crete: Minoan and Mycenaean Art from American and European Public and Private Collections. Northampton, Mass.: Smith College Museum of Art.

Evans, J.A. 1921-1935. The Palace of Minos at Knossos. 4 vols. London: Macmillan.

Evely, R.D.G. 1993. Minoan Crafts: Tools and Techniques. An Introduction. SIMA 92(1). Göteborg: Paul Åströms Förlag.

Immerwahr, S.A. 1990. Aegean Painting in the Bronze Age. University Park and London: The Pennsylvania State University Press.

Koehl, R.B. 1986. "The Chieftain Cup and a Minoan Rite of Passage." JHS 106:99-110.

. 2000. "Ritual Context." In The Palaikastro
Kouros: A Minoan Chryselephantine Statuette and Its Aegean Bronze Age Context, edited by J.A. MacGillivray, J.M. Driessen, and L.H. Sackett, 131-43. BSA Studies 6. London: British School at Athens.

. 2006. Aegean Bronze Age Rhyta. Prehistory Monographs 19. Philadelphia: INSTAP Academic Press.

Lapatin, K.D.S. 2002. Mysteries of the Snake Goddess: Art, Desire, and the Forging of History. New York: Houghton Mifflin.

MacGillivray, A. 2000. "The Great Kouros in Cretan Art." In The Palaikastro Kouros: A Minoan Chryselephantine Statuette and Its Aegean Bronze Age Context, edited by A. MacGillivray, J.M. Driessen, and L.H. Sackett, 123-30. BSA Studies 6. London: British School at Athens.

Morris, S.P. 1992. Daidalos and the Origins of Greek Art. Princeton: Princeton University Press.

Picón, C.A., J.R. Mertens, E.J. Milleker, C.S. Lightfoot, and S. Hemingway, eds. 2007. Art of the Classical World in the Metropolitan Museum of Art: Greece, Cyprus, Etruria, Rome. New Haven and London: Yale University Press.

Zettler, R.L., and L. Horne, eds. 1998. Treasures from the Royal Tombs of Ur. Philadelphia: University of Pennsylvania Museum Publications. 